\title{
Quantification of epicardial adipose tissue in morbidly obese patients before and after bariatric surgery
}

\author{
María Luaces ${ }^{1 *}$, Victoria Cachofeiro², Jorge Cabezudo Pedrazo ${ }^{3}$, Alfonso Antequera-Pérez ${ }^{3}$, Manuel Medina-García ${ }^{3}$, \\ Alejandro García- Muñoz ${ }^{3}$, Leopoldo Pérez de Isla ${ }^{1}$
}

From 17th Annual SCMR Scientific Sessions

New Orleans, LA, USA. 16-19 January 2014

\section{Background}

Epicardial adipose tissue is a highly complex endocrine organ that generates various molecules with profound local and systemic effects that can play a role in obesityrelated heart damage. Bariatric surgery is a last-step therapeutic option to ameliorate obesity. Objective: To compare the amount of epicardial adipose tissue, as well as anatomic and functional features of the heart, and metabolic profile of morbidly obese patients referred for bariatric surgery

\section{Methods}

Morbidly obese patients accepted for bariatric surgery were prospectively included. In each case, CMR was performed with a 1.5 equipment previous to surgery and with a $3 . T$ magnet 1 year after surgery. The epicardial adipose tissue (EAT) was assessed from a dark-blood prepared multislice turbo-spin echo pulse sequence to obtain short-axis images. The amount of EAT was calculated by using the modified Simpson's rule. The contours of epicardial adipose tissue were outlined covering the entire right and left ventricle (the figure 1). The EAT volume was obtained after the data summation of all slices. For LV structure and function, a conventional SSFPB protocol including short and long-axis slices was acquired. LV mass was calculated using a dedicated software. Pre and postoperative levels of glucose, triglyceride and cholesterol were compared.

\section{Results}

31 patients reached 1 year follow -up. Epicardial adipose tissue decreased by $31 \%$, and LV mass decreased by $26 \%$

${ }^{1}$ Hospital Clínico San Carlos, Madrid, Spain

Full list of author information is available at the end of the article (the table 1). Glucose and triglyceride levels showed also significant reductions

\section{Conclusions}

CMR is a robust technique to quantify epicardial adipose tissue in morbidly obese patients. The amount of epicardial adipose tissue shows a significant reduction in morbidly obese patients one year after bariatric surgery. This decrease is accompanied by substantial amelioration in metabolic control.

\section{Funding}

Fondo de Investigaciones Sanitarias. Instituto de Salud Carlos III. Ministry of Economy and Competitiveness of Spain. (PI09/0871 and PI09/2428).

Table 1

\begin{tabular}{|c|c|c|c|}
\hline$n=31$ & PRE & POST & $p$ value \\
\hline $\mathrm{BMI}(\mathrm{kg} / \mathrm{m} 2)$ & $46.42 \pm 5.61$ & $31.12 \pm 5.52$ & $<0.001$ \\
\hline $\begin{array}{l}\text { Epicardial adipose tissue } \\
\qquad(\mathrm{mm} 3)\end{array}$ & $79.8 \pm 30$ & $55.4 \pm 23.6$ & $<0.001$ \\
\hline LV mass $(\mathrm{g})$ & $113.4 \pm 24.9$ & $95.4 \pm 26.17$ & $<0.001$ \\
\hline LVEDV (ml) & $\begin{array}{c}153.86 \pm \\
30.17\end{array}$ & $156.55 \pm 19.9$ & 0.60 \\
\hline LVESV (ml) & $\begin{array}{c}56.62 \pm \\
16.28\end{array}$ & $56 \pm 19.9$ & 0.81 \\
\hline LV SV (ml) & $\begin{array}{c}97.88 \pm \\
24.29\end{array}$ & $101.02 \pm 20.8$ & 0.52 \\
\hline LVEF (\%) & $63.72 \pm 10.1$ & $64.7 \pm 5.56$ & 0.54 \\
\hline Glucose (g/dL) & $103.8 \pm 6.26$ & $83.9 \pm 3.36$ & 0.007 \\
\hline Triglyceride (mg/dL) & $\begin{array}{c}136.50 \pm \\
16.13\end{array}$ & $93.8 \pm 9.85$ & 0.022 \\
\hline
\end{tabular}

Data are expressed as mean \pm standard deviation. 

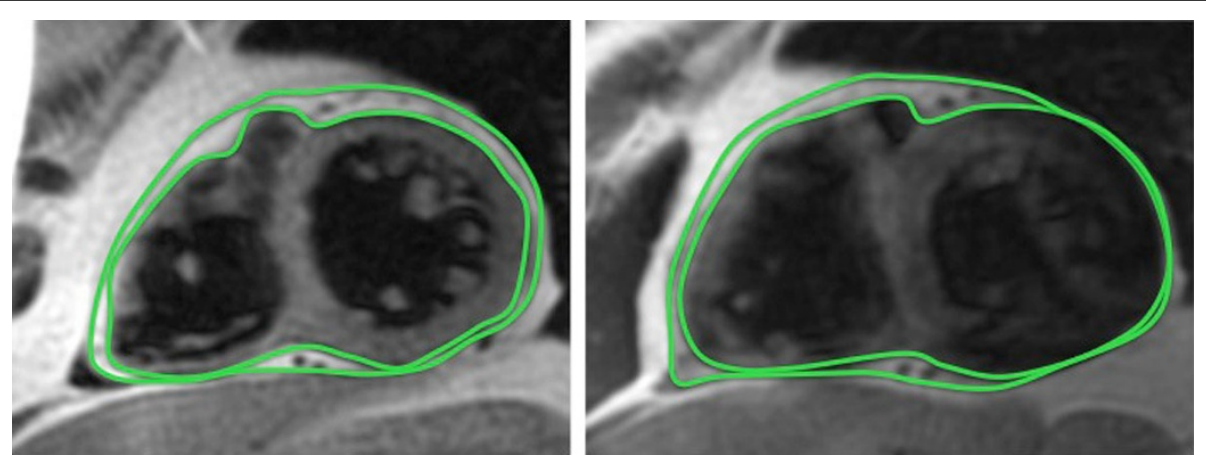

Figure 1 Short - axis dark- blood images showing the delineation of epicardial fat before (left) and after (right) bariatric surgery.

\section{Authors' details}

${ }^{1}$ Hospital Clínico San Carlos, Madrid, Spain. ${ }^{2}$ Physiology, Universidad

Complutense, Madrid, Spain. ${ }^{3}$ Hospital Universitario de Fuenlabrada,

Fuenlabrada, Spain.

Published: 16 January 2014

doi:10.1186/1532-429X-16-S1-P281

Cite this article as: Luaces et al:: Quantification of epicardial adipose

tissue in morbidly obese patients before and after bariatric surgery.

Journal of Cardiovascular Magnetic Resonance 2014 16(Suppl 1):P281.

\section{Submit your next manuscript to BioMed Central} and take full advantage of:

- Convenient online submission

- Thorough peer review

- No space constraints or color figure charges

- Immediate publication on acceptance

- Inclusion in PubMed, CAS, Scopus and Google Scholar

- Research which is freely available for redistribution

Submit your manuscript at www.biomedcentral.com/submit
Biomed Central 